\title{
Hepatitis B and C Single and Co-Infection Patterns Among Emergency Patients in a Resource-Limited Setting
}

\author{
Fasakin Kolawole Asimiyu ${ }^{1,}$, , Ajayi Oluwafemi David ${ }^{2}$, Esan Ayodele Jacob ${ }^{1}$, \\ Omisakin Christopher Tope ${ }^{1}$, Adams Olusegun Timothy ${ }^{3}$, Ojiezeh Tony Ifeanyi, \\ Aboderin Florence Ifechukwude ${ }^{5}$ \\ ${ }^{1}$ Department of Haematology, Federal Teaching Hospital, Ido Ekiti, Nigeria \\ ${ }^{2}$ Department of Pharmacology and Therapeutics, Afe Babalola University, Ado Ekiti, Nigeria \\ ${ }^{3}$ Department of Family Medicine, Federal Teaching Hospital, Ido Ekiti, Nigeria \\ ${ }^{4}$ Department of Medical Laboratory Science, Afe Babalola University, Ado Ekiti, Nigeria \\ ${ }^{5}$ Department of Haematology and Immunology, College of Health Sciences, Obafemi Awolowo University, Ile Ife, Nigeria
}

Email address:

fasakin_kolawole@yahoo.co.uk (Fasakin K. A.)

\section{To cite this article:}

Fasakin Kolawole Asimiyu, Ajayi Oluwafemi David, Esan Ayodele Jacob, Omisakin Christopher Tope, Adams Olusegun Timothy, Ojiezeh Tony Ifeanyi, Aboderin Florence Ifechukwude. Hepatitis B and C Single and Co-Infection Patterns Among Emergency Patients in a Resource-Limited Setting. American Journal of Biomedical and Life Sciences. Vol. 3, No. 3, 2015, pp. 55-60.

doi: $10.11648 /$ j.ajbls.20150303.15

\begin{abstract}
Background: Hepatitis B and C viral infections continue to constitute major global health problems and are responsible for most liver related deaths. This study is carried out to reveal the hepatitis $\mathrm{B}$ and $\mathrm{C}$ single and co-infection patterns among emergency patients and their possible liver outcomes. Methods: Two hundred and eighty-eight (288) patients on initial visit from casualty unit were routinely screened for hepatitis B and $\mathrm{C}$ viruses over a period of two years in the haematology department. Diaspot one step enzyme immunoassay rapid kits for hepatitis B surface antigen (HBsAg) and anti$\mathrm{HCV}$ respectively were used. $\mathrm{HBsAg}$ and anti-HCV seroprevalence and possible co-infections were evaluated using descriptive statistics of SPSS version 17 and expressed in mean and standard deviation, and male: female ratios. Results: Of the 288 research volunteers, $8.68 \%$ and $1.74 \%$ were positive for HBsAg and anti-HCV respectively. $1.04 \%$ was HBV and HCV co-infected. The overall mean age and male: female ratio were $44.4 \pm 17.3$ years and 1.4:1 respectively. Lower mean age and higher male: female ratios were observed in HBV and HCV population. HCC remain the major liver outcome in $\mathrm{HBV}$-infected and $\mathrm{HBV} / \mathrm{HCV}$ co-infected research subjects. Conclusion: Hepatitis $\mathrm{B}$ and $\mathrm{C}$ viral infections still remain a major public health problem globally. There is need for continued aggressive advocacy on 'Know your HBV and HCV status' to reduce the scourge of these infections especially in rural and resource-limited settings where problem of poverty and ignorance have contributed to development of liver complications in these patients.
\end{abstract}

Keywords: HBsAg, Anti-HCV, HCC, Seroprevalence, Male: Female Ratios, Gender Differences

\section{Introduction}

Hepatitis B virus (HBV) infection is a blood-borne disease of clinical importance and global health problem. Hepatitis B virus is a member of the Hepadnaviridae family and a DNA virus with partially double-stranded DNA and a core antigen surrounded by a shell containing hepatitis B surface antigen (HBsAg) and other antigenic components of diagnostic importance [1]. HBV is the leading cause of chronic liver disease and liver-related deaths worldwide with the majority of these cases occurring in areas of Africa and Asia.
Transfusion of blood and blood products, circumcision, social demographic factors, and medical and surgical risk factors have been implicated as factors associated with HBV transmission [2-7].

$\mathrm{HCV}$ is another major public health problem worldwide. It is an envelope virus with a single-stranded RNA genome and a diameter of about $50 \mathrm{~nm}$. $\mathrm{HCV}$ belongs to the genus Hepacivirus in the family of flaviridae. Most hepatitis $\mathrm{C}$ viral diagnosis has been on the basis of detectable antibodies to the virus in human serum or plasma [8-9]. Direct percutaneous inoculation is the most efficient mode of transmission of 
$\mathrm{HCV}$, but sexual, household, occupational, and vertical transmission may also be important.

Aside from human immunodeficiency virus (HIV), hepatitis $\mathrm{B}$ virus (HBV) and hepatitis $\mathrm{C}$ virus (HCV) constitute a major public health challenge globally and especially in sub Saharan Africa. It has been documented that $\mathrm{HBV}$ and $\mathrm{HCV}$ are the most common causes of liver diseases globally affecting approximately 350 million and 170 million people respectively [10-12]. In fact, according to World Health Organization (WHO), more than 1 million people die each year from disease caused by HBV and HCV while most of those infected are unaware of their status thereby increasing the risk of developing the risk of liver disease and transmitting the viruses to others. Africa has been reported to be the region with the largest number of chronic carriers of HBV after Asia and has been considered a region of high endemicity. Although the exact disease burden for HBV is difficult to assess due under-reporting and inaccurate records, about $70-95 \%$ of the adult population in Africa show evidence of past exposure to $\mathrm{HBV}$ infection and the estimated seroprevalence ranges from 6-20\% [13-14]. The prevalence of $\mathrm{HBV}$ infection in Nigeria was reported to be in the range of $2.4-18.4 \%$ [15-17]. On the other hand, HCV has a prevalence of $5.3 \%$ and an estimated 32 million people infected with HCV in Sub Saharan Africa making it the region with the highest burden of the disease in the world [18]. In Nigeria, previous studies recorded a prevalence of anti-HCV in the range of $3.6 \%$ to $5 \%[19,20]$.

$\mathrm{HBV}$ and HCV share a few similarities like their mode of transmission, hepato-tropism and the ability to cause chronic infections that may lead to the development of liver cirrhosis and hepatocellular carcinoma (HCC) [21-23]. Although there are some differences in the geographical distribution of the two viruses HBV is more prevalent in Far East, Sub-Saharan Africa, and Southern America with $2 \%-15 \%$ of populations infected, whereas HCV is more prevalent in Asia, NorthAfrica and Europe with $2.5 \%-10 \%$ of population infected), they quite frequently co-exist especially in countries at high endemicity for one or both viruses and among patients with a high risk of parenterally transmitted infections. The estimated global prevalence of $\mathrm{HBV} / \mathrm{HCV}$ dual infection is approximately 5\%-20\% in HBsAg positive patients and 2\%$10 \%$ in $\mathrm{HCV}$ positive patients, with a quite different geographical distribution, as reviewed by Caccamo et al [24]. Esan et al. reported a prevalence of $0.15 \%$ among pregnant women in southwest Nigeria [25].

Studies indicate that $\mathrm{HBV}$ and $\mathrm{HCV}$ co-infection is associated with increased risk of worse clinical outcomes such as advanced fibrosis or cirrhosis, decompensation, hepatocellular carcinoma, and transplantation compared with HCV mono-infection [10, 12, 26-30] but this co-infection is largely under reported in Africa despite its severe outcome and especially the risk individual infections pose to health workers in the laboratory and emergency department of a health facility. It is against this background that we have conducted this study to obtain an evidence-based data showing the single and co-infection patterns of hepatitis B and $\mathrm{C}$ viral infections among emergency patients reporting to our laboratory for HBV and HCV screening.

\section{Study Methods}

\subsection{Study Population}

The study population for this research study were two hundred and eighty-eight (288) emergency patients reporting to our laboratory for whom hepatitis $\mathrm{B}$ and $\mathrm{C}$ viruses screening were requested. Patients with already known status or those with Hepatitis B Virus vaccination within one week were excluded from the study.

\subsection{Study Location}

This study was carried out at the Haematology department of the Federal Teaching Hospital (FETHI), Ido Ekiti, Nigeria. FETHI was located in Ido Ekiti, the principal town in Ido Osi local government area of Ekiti state with an estimated population of 107,000 . It is geographically located in the northern part of Ekiti state which covers an estimated total area of $6353 \mathrm{~km}^{2}, 2,453$ square mile and an estimated population of $2,737,186$, where the routes from Kwara and Osun states converge. FTH, Ido Ekiti was upgraded in 2006 to formerly as a Centre for HIV/AIDS and other blood-borne infections including viral hepatitis $\mathrm{B}$ and $\mathrm{C}$ viruses referral, diagnosis and treatment in Ekiti State and serving five contiguous states. The Teaching Hospital since then has been offering diagnosis, prophylactic and therapeutic treatment for infected patients.

\subsection{Study Period}

This research study was carried out over a period of twenty-five months (February 2012 to February, 2014). Whole blood samples were collected following informed consent as part of the ethical consideration as the research participants presented themselves at our facility. Plasma/ sera were separated immediately and tested for HBsAg and anti$\mathrm{HCV}$ antibody within 4 hours of separation.

\subsection{Study Design}

\subsubsection{Hepatitis $B$ and C Viral Testing}

All patients who reported to our laboratory for emergency screening based on suspected hepatitis $\mathrm{B}$ and $\mathrm{C}$ viral infections were screened with Diaspot enzyme immunoassay (EIA) rapid diagnostic kits using plasma/serum separated from whole blood/clotted blood sample. Quality of results was established through the use of known HBV-infected volunteer and analyst's control.

\subsubsection{Statistical Analysis}

Data were analyzed with the descriptive analytical tool of the SPSS (Statistical Package for Social Sciences, Chicago, IL) version 17 software. Results were expressed in tables as means and standard deviations. 


\section{Results}

288 research participants who gave informed consent had their blood samples taken for analysis. The overall mean age and male: female ratio of research participants were $44.36 \pm$ 17.28 and 1.4:1 as shown in Table 1. Twenty-two (22) in all were seropositive for $\mathrm{HBsAg}$ giving a seroprevalence of $8.68 \%$; only five (5) were seropositive for anti-HCV, that is, anti-HCV seroprevalence was $1.74 \%$. The HBsAg and antiHCV were detected in only three (3) among the studied population giving the lowest seroprevalence of $1.04 \% \mathrm{~s}$ for $\mathrm{HBV} / \mathrm{HCV}$ co-infection observed in the study as shown in Table 2. The mean age and male: female ratios of infected patients according to the viral status were presented in Table 3. The mean age and male: female ratio for HBV-infected emergency patients were $39.1 \pm 17.2$ years (inter-quartile age range 17.2 -51.0 years) and $6.3: 1$. That of HCV-infected emergency patients were $30.2 \pm 10.9$ (inter-quartile age range: $18.5-39.5$ years) and $4: 1$ respectively. Finally, table 4 showed the HBV and HCV single and co-infection patterns among the emergency patients according to sex. 19 (86.4\%) out of the $22 \mathrm{HBV}$-infected and $4(80 \%)$ out of the $5 \mathrm{HCV}$ infected cases were males. The reverse was observed among $\mathrm{HBV} / \mathrm{HCV}$ co-infected counterpart where two female patients $(66.7 \%)$ had dual infection.

Furthermore, among the 22 research subjects positive for HBV, only eight $(36.36 \%)$ developed hepatocellular carcinoma and four $(18.18 \%)$ had transit liver cirrhosis while ten $(45.46 \%)$ were chronic carriers of HBV infection. No case of liver complication was noted among the anti-HCV positive research subjects.

Table 1. overall mean age \pm sd and male-female ratio of research participants.

\begin{tabular}{lllll}
\hline $\begin{array}{l}\text { Research } \\
\text { participants }\end{array}$ & $\begin{array}{l}\text { Mean } \\
\text { age(yrs) }\end{array}$ & Male & Female & $\begin{array}{l}\text { Overall Male- } \\
\text { Female Ratio }\end{array}$ \\
\hline 288 & $44.4 \pm 17.3$ & 168 & 120 & $1.4: 1$ \\
\hline
\end{tabular}

Table 2. Hepatitis B Surface Antigen And Anti-HCV Seroprevalence Among Emergency Patients.

\begin{tabular}{llll}
\hline Viral infection & Total No & No Positive & Prevalence (\%) \\
\hline HBsAg & 288 & 22 & 8.68 \\
HBsAg\& HCV Ab & 288 & 3 & 1.04 \\
HCV Ab & 288 & 5 & 1.74 \\
\hline
\end{tabular}

Table 3. Mean Age \pm Sd And Male-Female Ratio According To Viral Status.

\begin{tabular}{llll}
\hline HBsAg & HCV Ab & Mean \pm SD (yrs) & Male-Female Ratio \\
\hline Positive & Negative & $39.1 \pm 17.2$ & $6.3: 1$ \\
Negative & Positive & $30.2 \pm 10.9$ & $4: 1$ \\
Positive & Positive & $39.0 \pm 12.3$ & $1: 2$ \\
\hline
\end{tabular}

Table 4. hbv and hcv single and co-infection pattern among emergency patients according to sex.

\begin{tabular}{|c|c|c|c|c|c|c|c|c|c|}
\hline \multirow{3}{*}{ SEX } & HBsAg & $\% \mathrm{HBV}$ & Mean age & HCV Ab & $\% \mathrm{HCV}$ & Mean age & $\mathrm{HBV} / \mathrm{HCV}$ & $\% \mathrm{HBV} / \mathrm{HCV}$ & Mean age \\
\hline & \multicolumn{3}{|c|}{ Positive Positive } & \multicolumn{3}{|c|}{ Positive Positive } & \multicolumn{3}{|c|}{ Infection Infection } \\
\hline & (n) & $(\%)$ & (Yrs) & (n) & $(\%)$ & (Yrs) & (n) & $(\%)$ & (Yrs) \\
\hline MALE & 19 & 86.4 & $39.7 \pm 16.3$ & 4 & 80.0 & $32.8 \pm 9.3$ & 1 & 33.3 & $53.0 \pm 0.0$ \\
\hline FEMALE & 3 & 13.6 & $35.3 \pm 9.7$ & 1 & 20.0 & $20.0 \pm 0$ & 2 & 66.7 & $41.5 \pm 11.3$ \\
\hline
\end{tabular}

\section{Discussion}

The results of this study showed that 168 male subjects $(58.3 \%)$ and 120 female subjects $(41.7 \%)$ participated in the research study resulting in overall male: female ratio of 1.4:1. The overall mean age of research participants was $44.36 \pm 17.28$ years (inter-quartile age range: $31.0-58.0$ years). Our findings revealed $\mathrm{HBV}$ and $\mathrm{HCV}$ seroprevalence of $8.68 \%$ and $1.74 \%$ respectively and corresponding mean age and male: female ratios of $39.1 \pm 17.2$ years (inter-quartile age range17.2 -51.0 years), 6.3:1 and 30.2 \pm 10.9 (interquartile age range: $18.5-39.5$ years), 4:1 respectively among emergency patients. These research outcomes were slightly higher than HBV seroprevalence reported by Tuba and his co-researchers [31] and Gabor et al [32] who reported 5\% among Turkish critically ill emergency patients and those from emergency department of Johns Hopkins University respectively. Anti-HCV seroprevalence among emergency patients reported in this study is more than eleven times that reported by Esan et al. [25] among pregnant women attending the antenatal clinic of this same institution. Esan and his colleagues reported $0.15 \%$ among pregnant women while the finding among emergency patients was $1.74 \%$. This suggests other risk factors such as the use of injection drugs, percutaneous infections, alcoholism and smoking, and to a lesser extent sexual risk behaviour which is more prevalent among men may be responsible for this. Gender difference in HBsAg and antiHCV antibody prevalence was clearly shown. We found that the HBsAg and anti-HCV antibody prevalence was significantly higher in males than females $(\mathrm{p}<0.01)$. Of the HBV-infected population, nineteen $(86.4 \%)$ were males and $3(13.6 \%)$ were females with mean age of $39.7 \pm 16.3 \mathrm{yrs}$ and $35.3 \pm 9.7 \mathrm{yrs}$ respectively. The results of this study is concordance with two recent large series study from Greece and New Zealand and another by Pei-Kwei and his coresearchers which showed a higher HBsAg prevalence in males than females [33-35]. However, this is in contrast to the findings in Taiwan patients where HBsAg prevalence between genders was not significantly different in 
epidemiologic studies in Taiwan [36-38]. The prevalence of $\mathrm{HBV} / \mathrm{HCV}$ co-infection was $1.04 \%$ with male: female ratio $1: 2$ and mean age $39.0 \pm 12.3$ (inter-quartile age range: 30.0 53.0 years).

Moreover, more than $45 \%$ (45.46\%) of the 22 emergency patients positive for $\mathrm{HBsAg}$ were chronic carriers of hepatitis B, some of which were unaware of their status until tested and were patents that were screened for hepatitis $\mathrm{B}$ viral infection during their initial visit. Of the remainin twelve $(54.54 \%)$, four $(18.18 \%)$ had transit liver cirrhosis and eight (36.36\%) developed hepatocellular carcinoma (HCC). This showed hepatocellular carcinoma to be most common hepatic disease that results from $\mathrm{HBV}$ infection. We could not ascertain the frequency of HCC in the anti-HCV positive emergency patients. It seems not to be a common occurrence here. Of the three patients who had HBV and HCV co-infections, only two (one male and another female patients) had evidence of hepatic trauma. We can probably attribute the development of HCC in these patients to dominance of $\mathrm{HBV}$ infection. $\mathrm{HBV}-\mathrm{HCV}$ infections in this other female patient could not be confirmed as there is no observed hepatic disease. The outcomes of this research corroborated the report of the International Agency for Research on Cancer in 1994. The agency analyzed multiple cohort and case control studies and reported that there was sufficient evidence in humans for the carcinogenicity of chronic HBV infection [39]. The relative risk of HCC among people infected with HBV ranges from 5-49 in case control studies and 7 to 98 in cohort studies [40]. Recently, a nomogram was introduced for the calculation of the risk of developing HCC based on risk factors such as male gender, older age, family history of HCC, use of alcohol or tobacco, high serum HBV DNA levels, HBV genotype C, co-infection with $\mathrm{HCV}$, HIV or hepatitis delta virus, increased serum alanine aminotransferase and presence of liver cirrhosis[41-42]. These tools can be very helpful for the clinicians while counselling patients regarding preventive measures and potential strategies to decrease risk of HCC.

\section{Conclusion}

Hepatitis $\mathrm{B}$ and $\mathrm{C}$ viral infections still remain a major public health problem globally. There is need for continued aggressive advocacy on 'Know your HBV and HCV status' to reduce the scourge of these infections especially in rural and resource-limited settings where problem of poverty and ignorance have contributed to development of liver complications in these patients. All tiers of government in Nigeria, and by extension, every nation should have a wellestablished public enlightenment, screening and vaccination programmes. All factors that can contribute to increased risk of hepatocellular carcinoma in infected patients should be avoided especially in men.

\section{Acknowledgements}

The authors acknowledged Dr Busari OA for his expert advice during the preparation of this manuscript and staff of the blood bank laboratory for their support.

\section{References}

[1] Adam I, Gassim GI and Murad IA (2013). Hepatitis B and C virus infections among pregnant women in Arab and African countries. Journal of Infectious Disease in Developing Countries 8:566 578.

[2] El-Faramawy AA, El-Rashidy OF, Tawfik PH, Hussein GH (2012) Transfusion transmitted hepatitis: where do we stand now? A one centre study in upper Egypt. Hepatology Mon 12: 286-291.

[3] Khan S, Attaullah S (2011) Share of Afghanistan populace in hepatitis B and C infection's pool: Is it worthwhile? Virology Journal; 8: 21.

[4] Rabiu KA, Akinola OI, Adewumi AA, Omololu OM, Ojo TO (2010) Risk factors for hepatitis B virus infection among pregnant women in Lagos. Acta Obstetricia et Gynaecologica 89:1024- 1028 .

[5] El-sheikh RM, Daak AA, El-sheik MA, Kahsany MS, Adam I (2007) Hepatitis B virus and Hepatitis C virus in pregnant Sudanese women. Virology Journal 4: 104.

[6] Mansour W, Malick FZ, Sidiya A, Ishagh E, Chekarau MA, Veillon P, Ducancelle A, Brichler S, Le Gal F, Lo B, Gordien E, Lunel-Fabiani F (2012) Prevalence, risk factors and molecular epidemiology of hepatitis B and hepatitis delta virus in pregnant women and in patients in Mauritania. Journal of Medical Virology 84: 1186-1198.

[7] Mohebbi SR, Sanati A, Cheraphipour K, Rostami Nejad M, Shalmani HM, Zali MR (2011) Hepatitis C and Hepatitis B virus Infection: Epidemiology and risk factors in a large Cohort of Pregnant Women in Lorestan, West of Iran. Hepatology Mon 1: 736-739.

[8] Fiekumo IB, Musa AM and Zacchaeus AJ (2009). Seroepidemiology of transfusion-transmissible infectious diseases among blood donors in Osogbo, South-west, Nigeria. Blood Transfusion 7(4):293-299.

[9] Erhabor O, Ejele OA, Nwauche CA (2006): The risk of transfusion acquired hepatitis $\mathrm{C}$ virus infection among blood donors in Port-Harcourt: The question of blood safety in Nigeria. Nigerian Journal of Clinical Practice 9(1):18-2

[10] Bini EJ, Perumalswami PV. Hepatitis B virus infection among American patients with chronic hepatitis $\mathrm{C}$ virus infection: prevalence, racial/ethnic differences, and viral interactions. Hepatology. Mar; 2010 51(3):759-766. [PubMed: 20140950]

[11] Brass V, Moradpour D. New insights into hepatitis B and C virus co-infection. J Hepatol. Sep; 2009 51(3):423-425. [PubMed: 19596479]

[12] Crockett SD, Keeffe EB. Natural history and treatment of hepatitis B virus and hepatitis C virus coinfection. Ann ClinMicrobiolAntimicrob. 2005; 4:13. [PubMed: 16159399]

[13] Kiire CF and the African Regional Study Group. Hepatitis B infection in sub-Saharan Africa. Vaccine. 1990; 8:S107-S112. 
[14] Kiire CF. The epidemiology and prophylaxis of hepatitis B in sub-Saharan Africa: a view from tropical and subtropical Africa. Gut. 1996; 37(suppl 2):S5-S12.

[15] Ndako JA, Nwankiti OO, Echeonwu GON, Junaid SA, Anaele O, Anthony TJ (2011). Studies on Prevalence and Risk Factors for Hepatitis B Surface Antigen among Secondary School Students in North-central, Nigeria. Sierra Leone J. Biomedical Res. 3 (3): 163-168.

[16] Olokoba AB, Salawu FK, Danburam A, Desalu OO, Olokoba LB, Wahab KW, Badung LH, Tidi SK, Midala J, Aderibigbe S, Abdulrahman MB, Babalola OM, Abdukkarim A (2009). Viral Hepatities in Voluntary Blood Donors in Yola, Nigeria. Euro. J. Scientific Res. 31 (3): 329-334.

[17] Ugwuja EI, Ugwu NC (2010). Seroprevalence of Hepatitis B Surface Antigen and Liver Function Tests among Adolescents in Abakaliki, South Eastern Nigeria. The Internet J. Trop. Med. $6(2): 1-6$.

[18] WHO. Weekly Epidemiological Record. 1999 22.08.2012; 49(10): Available from: http://www.who.int/docstore/wer.

[19] Duru MU, Aluyi HAS, Anukam KC (2009). Rapid screening for co-infection of HIV and HCV In pregnant women in Benin City, Edo state, Nigeria. Afr Health Sci.; 9: 137-142.

[20] Ugbebor O, Aigbirior M, Osazuwa F, Enabudoso E, Zabayo O (2011). The prevalence of hepatitis B and C viral infections among pregnant women. North Am. J. Med. Sci. 3 (5): 238241.

[21] World Health Organization Executive Board (2009). Viral hepatitis. Report by the Secretariat. EB126/15, 12 November 2009. Available from: URL: http://apps.who.int/gb/ebwha/pdf_files/EB126/B126 15en.pdf

[22] World Health Organization. Prevention and control of viral hepatitis infection. Framework for global action. Available from:

URL: http://www.who.int/csr/disease/hepatitis/GHP_Framework_En .pdf

[23] Perz JF, Armstrong GL, Farrington LA, Hutin YJ, Bell BP. The contributions of hepatitis B virus and hepatitis $C$ virus infections to cirrhosis and primary liver cancer worldwide. J Hepatol 2006; 45: 529-538 [PMID: 16879891]

[24] Caccamo G, Saffioti F, Raimondo G. Hepatitis B virus and hepatitis C virus dual infection. World J Gastroenterol 2014; 20(40): 14559-14567 Available from: URL:http://www.wjgnet.com/10079327/full/v20/i40/14559.htmDOI:http://dx.doi.org/10.3748/wj g.v20.i40.14559

[25] Esan AJ, Omisakin CT, Ojo-Bola T, Owoseni MF, Fasakin KA, and Ogunleye AA. Sero-Prevalence of Hepatitis B and Hepatitis C Virus Co-Infection among Pregnant Women in Nigeria. American Journal of Biomedical Research, 2014 2(1): $11-15$

[26] Chu CJ, Lee SD. Hepatitis B virus/hepatitis C virus coinfection: epidemiology, clinical features, viral interactions and treatment. J GastroenterolHepatol. Apr; 2008 23(4):512520. [PubMed: 18397482]
[27] Amin J, Law MG, Bartlett M, Kaldor JM, Dore GJ. Causes of death after diagnosis of hepatitis B or hepatitis $\mathrm{C}$ infection: a large community-based linkage study. Lancet. Sep 9; 2006 368(9539):938-945. [PubMed: 16962883]

[28] Sagnelli E, Coppola N, Pisaturo M, Masiello A, Tonziello G, Sagnelli C, et al. HBV superinfection in HCV chronic carriers: a disease that is frequently severe but associated with the eradication of HCV. Hepatology. Apr; 2009 49(4):1090-1097. [PubMed: 19263473]

[29] Fong TL, Di Bisceglie AM, Waggoner JG, Banks SM, Hoofnagle $\mathrm{JH}$. The significance of antibody to hepatitis $\mathrm{C}$ virus in patients with chronic hepatitis B. Hepatology. Jul; 1991 14(1):64-67. [PubMed: 1648540]

[30] Lin L, Verslype C, van Pelt JF, van RM, Fevery J. Viral interaction and clinical implications of coinfection of hepatitis $\mathrm{C}$ virus with other hepatitis viruses. Eur J GastroenterolHepatol. Dec; 2006 18(12):1311-1319. [PubMed: 17099381]

[31] Tuba Cimmili Ozturk, Ozlem Gunetsel, Adem Tali, Sonay Ezgi Yildirim, Ozge Ecmel Onur, Serpil Yaylaci. Hepatitis B Hepatitis C and HIV seroprevalence in critically ill emergency medicine department patients in a tertiary inner city hospital in Istanbul, Turkey. Pak J Med Sci 2014; 30(4): 703-707.

[32] Gabor D. Kellen, Gary B. Green, Robert H. Purcell, Daniel W. Chan, Bahjat F. Qaqish, Keith T. Silvertson and Thomas C. Quinn. Hepatitis B and hepatitis C in emergency department patients. NEngl J Med 1992; 1399-404.

[33] Koulentaki M, Spanoudakis S, Kantidaki E, Drandakis P,Tzagarakis N, Biziagos E, Moschandrea J, Kouroumalis EA. Prevalence of hepatitis B and C markers in volunteer blood donors in Crete. A 5-year study. J Viral Hepat1999;6:243-8.

[34] Robinson T, Bullen C, Humphries W, Hornell J, Moyes C.The New Zealand Hepatitis B Screening Programme: Screening coverage and prevalence of chronic hepatitis B infection. $N Z$ Med J 2005; 118:U1345.

[35] Pei-Kwei Tsay, Dar-In, Yu-Ming Chen, Cheng-Pin, Yu, Shy-Yi Wan, Deng-Yn Lin. Impact of Gender, Viral Transmission and Aging in the Prevalence of Hepatitis B surface Antigen. Chang Gung Med J 2009; 32(2):155-162.

[36] Chen DS, Sung JL, Lai MY. A sero-epidemiologic study of hepatitis B virus infection in Taiwan. Taiwan Yi Xue HuiZa Zhi 1978; 77:908-18.

[37] Sung JL, Chen DS, Lai MY, Yu JY, Wang TH, Wang CY,Lee CY, Chen SH, Ko TM. Epidemiological study onhepatitis B virus infection in Taiwan. Chin J Gastroenterol 1984;1:1-9.

[38] Lin HH, Huang LC, Lin DY. Hepatitis B virus infection in Eastern Taiwan: Viewed from a regional general hospital. $T z ' u$ Chi Med J 1992; 4: 94-99.

[39] World Health Organization; International Agency for Research on Cancer. IARC Monographs on the Evaluation Carcinogenic Risks to Humans. Volume 59; Hepatitis Viruses. Lyon, France; International Agency for Research on Cancer; 1994.

[40] Renumathy Dhanasekaran, Alpna Limaye, Roniel Cabrera. Hepatocellular carcinoma: current trends in worldwide epidemiology, risk factors, diagnosis and therapeutics. Hepatic Medicine; Evidence and Research 2012; 4: 19-37. 
[41] Nguyen V T, Law M G, Dore G J; Hepatitis B-related hepatocellular carcinoma: epidemiological characteristics and disease burden. $J$ Viral Hepat 2009; 16 (7): 453-463.
[42] Yang H I, Sherman M, Su J, et al. Nomograms for risk of hepatocellular carcinoma in patients with chronic hepatitis B virus infection. J Clin Oncol 2010; 28 (14): 2437-2444. 